University of Michigan Law School

University of Michigan Law School Scholarship Repository

\title{
The Effect of the Carmack Amendment to the Hepburn Act Upon Limitation by Common Carriers of the Amount of their Liability
}

\author{
Edwin C. Goddard \\ University of Michigan Law School
}

Available at: https://repository.law.umich.edu/articles/1005

Follow this and additional works at: https://repository.law.umich.edu/articles

Part of the Commercial Law Commons

\section{Recommended Citation}

Goddard, Edwin C. "The Effect of the Carmack Amendment to the Hepburn Act Upon Limitation by Common Carriers of the Amount of their Liability." Mich. L. Rev. 11 (1913): 588-91.

This Article is brought to you for free and open access by the Faculty Scholarship at University of Michigan Law School Scholarship Repository. It has been accepted for inclusion in Articles by an authorized administrator of University of Michigan Law School Scholarship Repository. For more information, please contact mlaw.repository@umich.edu. 


\section{Michigan LaW ReVieW}

PUBLISHED MIONTALY DURING THE ACADEMIIC YRAR, EXCLUSIVE OF OCTOBER, BY THE* LAW FACULTY OF THE UNIVERSITY OF MICHIGAN

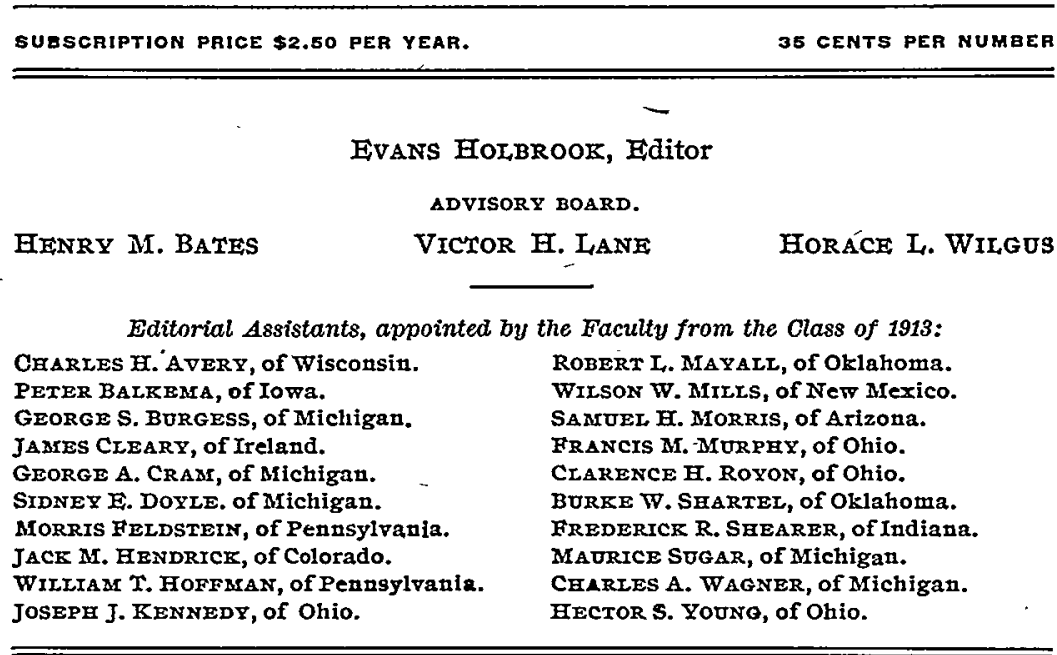

\section{NOTE AND COMMENT.}

The Effect of the Carmack amendment to the Hepburn Act Upon Limitation by Common Carriers of the Amount of thetr Liability.-Two cases, decided by the Supreme Court of the United States on March Io, I9r3, may be considered together. They are developments of the cases reviewed in II MICH. L. REv. 460. Plaintiff shipped two boxes and a barrel of "household goods" under an agreement that the goods, in case of loss, should be valued at $\$ 5$ per hundred-weight. One box, weighing not over 200 pounds and actually worth $\$ 75$, was lost. The Supreme Court of Arkansas affirmed a judgment against the carrier for the full value. 9I Ark. 97, I2I S. W. 932, 134 A. S. R. 56. On error the Supreme Court of the United States reversed and remanded the case for further proceedings. Kansas City Southern Ry. Co. v. Carl, 33 Sup. Ct. 39I. In the other case the plaintiff shipped four bulls and thirteen cows, "show cattle," worth \$10,640. The finding of the Texas Court of Civil Appeals, I28 S. W. 932 , was reversed on the ground that the recovery should have been limited to $\$ 30$ for each bull and $\$ 20$ for each cow, 
in accordance with the bill of lading. Missouri, Kansas \& Texas Ry. Co. v. Harriman Bros., 33 Sup. Ct. $39 \%$.

In II MICE. L. REv. 460, the Croninger and Miller cases were reviewed with the concluding statement that further decisions on this question will be awaited with interest. We now have these further cases. They dispose of some of the open questions, but not even these give a final answer to the question of the validity of an arbitrary valuation in a bill of lading, bearing no relation to the known value of the goods shipped, which has been fixed by carrier and shipper for the alleged purpose of securing a lower rate of shipment, under an agreement that goods are shipped "at owner's risk", but with an option to ship "at carrier's risk" at a higher rate. In neither of these cases does it appear that the carrier knew the true value of the goods, and the court expressly says that in this decision they "lay on one side, as not here involved, every question which might arise when it is shown that the carrier intentionaly connived with the shipper to give him an illegal rate, thereby causing a discrimination or preference forbidden by the positive terms of the act of Congress and made punishable as a crime." In the first case household goods were shipped, and these are not ordinarily valued by the hundred-weight, nor are such goods usually shipped when they are worth as little as $\$ 5$ per hundred-weight. However, it is conceivable that one might ship such goods, and as they were in this case in boxes and barrels, the carrier had no means, except the statement of the shipper, by which to determine their value. In the second case very valuable animals were shipped. It would be a poor sort of a bull that is worth only $\$ 30$ or a cow that is valued at $\$ 20$, but there are such, and it appears that the agent never saw these cattle.

It is perfectly plain that not all animals of a kind have the same fixed value. The court, however, finds that it is not unreasonable, for the purpose of fixing freight rates and publishing tariffs, to make two classifications; those above and those below a fixed maximum amount. This, the court says, is the only practicable method and has been administratively approved by the Commerce Commission. The quotation the court gives, hawever, from the finding of the Commission, approves of a graduation of rates in accordance with the actual values of specific commodities. It does not say that all commodities of less than a certain value shall be shipped at one rate, and all like commodities worth more than that amount, no matter how much more, shall be shipped at another rate, with no variations for intermediate valuations. Not only does the court approve of such a classification, but it holds that the shipper must take notice of it, and if he ships goods worth more than the amount fixed, he obtains an advantage and causes a discrimination forbidden and made unlawful by the El.kins Acr. (32 Stat. AT L. 847, Ch. 708, U. S. Conr. Stat. Supp. IgII, p. I309.) Query-Can the carrier in such a case have an action against the shipper to recover the greater rate? It has been held, and the court holds in this case, citing authorities therefor, that the carrier, if he carries at a less rate, cannot be compelled to surrender the goods until the full legal rate has been paid. Indeed the carrier violates the 
Exkins Acr if he does not insist upon the rate for the true value. But the shipper apparently, if he makes a mistake in the valuation, has no such right to correct his mistake, pay the additional charges and collect the full value of his goods. If he has by wilful misrepresentation misled the carrier, he is hardly in position to complain, but if, as usually happens, he had no intention to mislead, and simply accepted the bill of lading as it was offered him, without any questions asked, it is not easy to see why he should not have the same right to claim full value as the carrier has to claim full rates. The whole difficulty would soon settle itself if the courts held the carrier to liability for the actual value of the goods, unless it appears that he has in goodd faith tried to learn their real value and thas been deceived by the shipper. It can scarcely be claimed that the present method of fixing valuations in bills of lading represents any honest attempt by the carrier to learn the true worth of what he carries. Rather it represents a persistent, and finally successful, effort on the part of the carrier to find a way that will be approved by the court by which he may cut down the liability.

The language of the court in the Carl case is significant, and suggests, at least, that the court when squarely confronted with the problem will make the distinction so well set forth by Commissioner LANE in Re Released Rates, I3 I. C. C. R. 550, between attempts in good faith by the carrier to learn the value of the goods, and anbitrary valuations known by the courts not to represent such value. The language of the court is worth quoting: "An agreement to release such a carrier for part of a loss due to negligence is no more valid than one whereby there is complete exemption. Neither is such a contract any more valid because it rests upon a consideration than if it was without consideration."

The court squarely places the ground of limitation of recovery to the declared or agreed value upon estoppel. In cases where the shipper has really misled the carrier as to the value of his goods this is certainly sound. If, however, the carrier knew the shipper was not naming the real value, then he was not misled, he did not fix his rate in reliance upon misrepresentation, and the grounds of estoppel seem to be absent.

Again, the court says in this case, as has been said in substance in many cases, "If such a valuation be made in good faith, for the purpose of obtaining a lower rate $* * *$." Further on the court says that such an undervaluation is a misrepresentation and a violation of the Errksns Acr. How can a wilful misrepresentation be made in good faith? The two statements seem to be mutually contradictory. If this were a private matter, and carrier and shipper had connived, the courts might well leave them where they are, but it is not a private matter, and to allow the carrier to escape his liability by making such agreements with shippers encourages him to induce all shippers to undervalue, as in practice nearly always happens, and this is pretty clearly contrary to public policy. The carrier by making the difference in rates excessive, may drive all to undervalue the goods shipped, for if they do not, they are, as the court points out in the present cases, subject to discrimination, which is a violation of the 'EIRINS IAW. There is plenty of evidence that practically all shippers do take the lower rate. See II MICH. L. REv. 464. 
This leads to the last and possibly most important point of these decisions. In II MICH. I. REv. 463, it is insisted that there has never been a scientific and thorough determination of differences in carrying charges based on the greater or less risk of the carrier. The Harriman case certainly furnishes a glaring instance of manifestly improper charge, though in this case it happens not to be in the carrier's favor. The "cost at carrier's risk" was "I20 per cent of the rates named in this tariff." Shipments at this higher rate were made "without limitations of carrier's liability at common law" A more unscientific table of insurance rates could hardly be made. Certainly the Harriman Bros. could not complain of paying 120 per cent of ordinary rates in order to increase their insurance from $\$ 380$ to $\$ 10,640$. This might seem to furnish some evidence that the public does not care for insurance by the carrier at all. More probably it shows that the custom to take the lower rate is so universal that the agent of the carrier never shows the shipper any other bill of lading. It would be interesting to know if the agent of the carrier in the present case even had such a bill of lading that could be shown, and if the Harriman Bros. really knew that by paying 20 per cent greater carrying charges they could have increased their insurance from $\$ 380$ to $\$ 10,640$. The important point of this case is that the court decides that this question of whether the difference between two rates upon the same commodity is no more than a reasonable charge by the carrier for the larger responsibility, is an administrative question, to be determined by the Interstate Commerce Commission and not by the courts. So far as the courts are concerned; the filed and published tariffs must be assumed to have been properly fixed. If the present rates are not adequate to protect both carrier and shipper, the remedy is by an order of the Commission readjusting the rates. This seems to be a very satisfactory solution, although the finding of the Commission can scarcely be final, for the question of the reasonableness ot an order of the Commission is always subject to judicial determination. The contention of the shipper in the Carl case-that the rates were not properly adjusted-the courts refused to consider. This is doubtless on the ground that either carrier or shipper must first get an order from the Commission
before the courts will consider this question.

Notwithstanding the valuable additions to the law indicated above, we must still wait for a final determination of the troublesome question whether an arbitrary valuation, known by the carrier to bear no relation to the real worth of the goods, a misrepresentation made for the purpose of securing cheaper rates of shipment, is valid. It is interesting to note that in the Carl case Mr. Justice Hughes and Mr. Justice PrTney dissent, and that in the Harriman Bros. case Mr. Justice HugHes concurs in the result, while Mr. Justice Pirney dissents. The ground of these dissenting views is not given in the advanced sheets, but the fact that there is dissent, and many of the statements in the opinions written by Mr. Justice LURTON, give some ground for the hope that the United States Supreme Court, when it finally passes on this matter, will agree with the view so ably set forth by Commissioner LANE in Re Released Rates, I3 I. C. C. R. 550 . $\quad$ E. C. G. 